\title{
Surface-Water Quality Information in Connecticut: Answering Key Scientific and Management Questions
}

\section{Water-Quality Monitoring in Connecticut - How Did the Program Originate?}

The U.S. Geological Survey (USGS) and the State of Connecticut have worked together since 1955 to monitor and interpret the water quality of Connecticut's streams and rivers. An expanded cooperative water-quality monitoring program with the Connecticut Department of Environmental Protection (CTDEP) began in 1974, in response to the passage of Connecticut's Clean Water Act in 1967 and the Federal Water Pollution Control Act in 1972. These acts focused on regulation and treatment of municipal and industrial wastes. Consequently, the expanded monitoring program that resulted from these laws has emphasized streams that receive wastewater discharges. Waterquality data generated by this program are used by CTDEP to assess water quality for major rivers and streams, as required under sections 305 (b) and 303 (d) of the Federal Clean Water Act.
The water-quality monitoring program increased from 7 stations in 1968 to a peak of 45 stations in 1976 , was reduced to 30 stations in 1992, and includes 34 stations in 1998. Reductions in the number of stations, sampling frequencies, or the number of constituents analyzed have been driven largely by funding constraints rather than by program requirements.
Management decisions of increasing complexity require information suitable for protection and restoration of water quality, aquatic life, and habitat in rivers, lakes, and Long Island Sound.

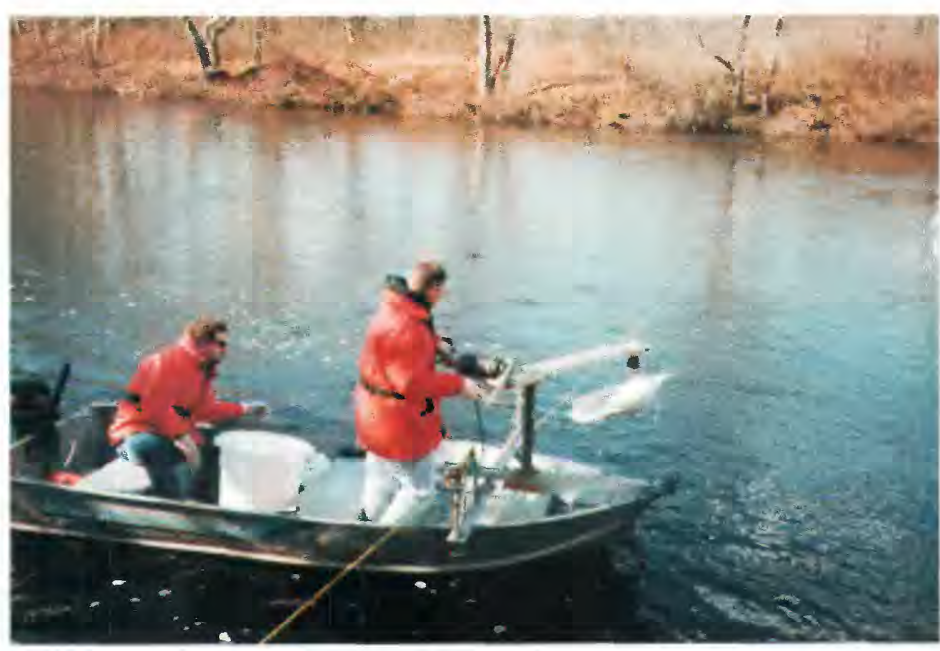

Water-quality sampling on the Quinebaug River near Jewett City (photograph by Jonathan Morrison, U.S. Geological Survey).

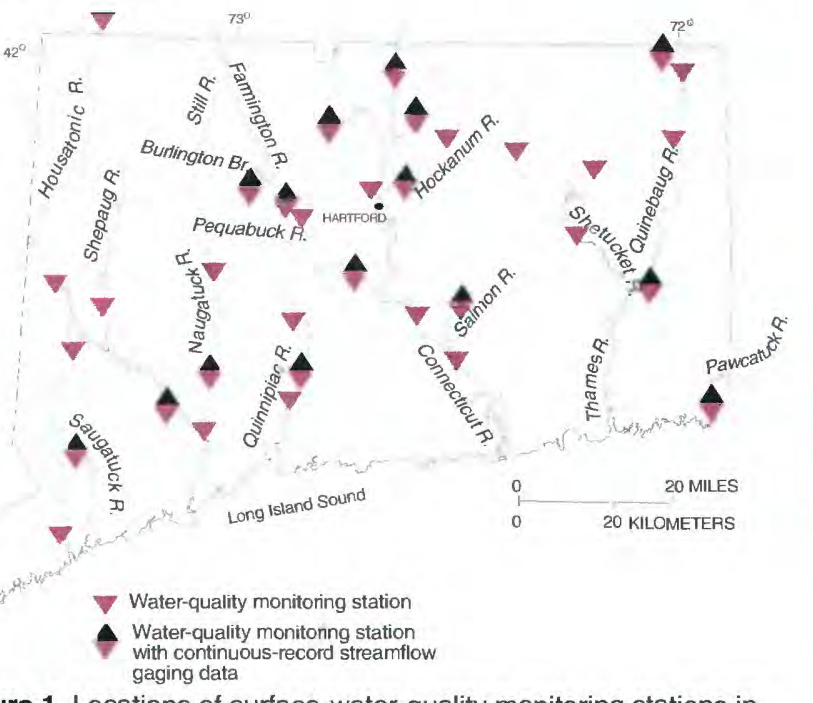

Figure 1. Locations of surface-water-quality monitoring stations in Connecticut, 1998

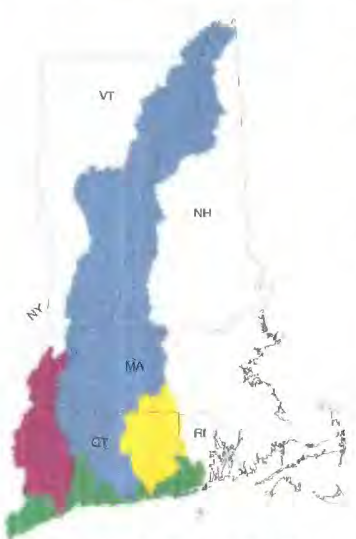

RIVER BASINS

Connecticut

Housatonic

Thames

Coastal

\section{Today's Water-Quality Monitoring Program - What are its Features?}

In 1998, the cooperative program to monitor surface-water quality consists of 34 stations (fig. 1):

- 7 in the Thames River Basin,

- 13 in the Connecticut River Basin,

- 8 in the Housatonic River Basin, and

- 6 in coastal drainage basins.

The monitoring stations are located on the State's largest rivers, interstate rivers, waste-receiving streams, and several streams where water quality is relatively unimpaired by human activities. Water quality has been monitored at these 34 stations for periods ranging from 33 years to less than 4 years. 
Water samples are collected yearround, but since 1992 sampling has been more frequent during summer than in winter. At most stations, each sampling event results in measurements of 48 physical, chemical, and bacteriological characteristics of the stream on that date. These measurements include 3 physical properties, 17 major chemical constituents and related properties, 2 forms of bacteria, 10 forms of 2 nutrients, and 16 trace metals.

\section{Information Objectives of the Current Program - Can Key Questions Be Answered?}

Management decisions of increasing complexity require a monitoring program that provides data for multiple purposes, including development of water-quality standards, classification of waters, protection and restoration of rivers and lakes, regulation of wastewater discharges and nonpoint sources of pollution, protection of aquatic life and habitat, integrated watershed management, and management and restoration of water quality and habitat in Long Island Sound. Answers to the following questions illustrate how the monitoring program can meet the needs of natural-resource managers for scientific information.

\section{Does the monitoring program represent Connecticut's diverse landscape?}

Even a small state such as Connecticut needs an extensive water-quality monitoring network to accurately represent the diverse conditions of the landscape, both in natural features and in human use of land and water resources. Natural variations in geology, topography, and climate are the principal factors affecting water quality in forested drainage basins. In basins with large areas of developed land, the most prominent effects on water quality are from municipal and industrial point discharges, and polluted runoff (nonpoint-source pollution) from urban and agricultural areas. Additionally, some streams that flow through Connecticut are affected by land use in other states.

Currently (1998), the monitoring program emphasizes large drainage basins (greater than 100 square miles) with diverse land uses; interstate rivers; and basins that receive point-source discharges (table 1). By contrast, few of the monitored drainage basins are less than 50 square miles in size, and only one has an area of less than 10 square miles. Small drainage basins with relatively homogeneous land use and no point-source discharges show effects of specific land uses or natural factors more clearly than large, diverse basins, because fewer variables affect water quality. Only limited water-quality information is available for small drainage basins with various intensities of urban and agricultural land use; forested drainage basins that are not experiencing suburban development; and urbanized southwestern coastal basins.

\section{What is the natural quality of streams in Connecticut?}

No drainage basins or streams in Connecticut represent completely natural conditions because contaminants are transported and deposited by the atmosphere. Nonetheless, it is important to determine the water-quality characteristics of streams that represent near-natural conditions in Connecticut. This information provides a baseline or reference in these and other basins to determine the extent to which stream quality has been affected by human activities. Baseline information shows typical concentrations of chemical constituents in uncontaminated streams. helps to identify constituents not found under natural conditions, and describes water-quality conditions in high-quality aquatic habitat.

Clean streams that drain sparsely developed. forested basins typically have higher concentrations of dissolved oxygen, lower turbidity, and lower concentrations

$\begin{gathered}\text { Median total nitrogen } \\ \text { concentration } \\ \text { (in milligrams per } \\ \text { liter) }\end{gathered}$
$0.0-0.5$
$0.51-1$
$1.1-2$
$2.1-6$

Table 1. Characteristics of monitored drainage basins in Connecticut $\left[\mathrm{mi}^{2}\right.$, square miles]

\begin{tabular}{|c|c|}
\hline Characteristic & $\begin{array}{l}\text { Number of } \\
\text { monitored } \\
\text { basins }\end{array}$ \\
\hline \multicolumn{2}{|c|}{ Topography and Geology } \\
\hline Eastern and western uplands & 20 \\
\hline Central lowland & 6 \\
\hline Coastal lowland & 1 \\
\hline Mixed & 7 \\
\hline \multicolumn{2}{|c|}{ Location of Basin } \\
\hline Interstate & 18 \\
\hline Within Connecticut & 16 \\
\hline \multicolumn{2}{|c|}{ Drainage Basin Size } \\
\hline Less than or equal to $50 \mathrm{mi}^{2}$ & 6 \\
\hline 51 to $100 \mathrm{mi}^{2}$ & 7 \\
\hline 101 to $500 \mathrm{mi}^{2}$ & 13 \\
\hline Greater than $500 \mathrm{mi}^{2}$ & 8 \\
\hline \multicolumn{2}{|c|}{ Pollution Sources } \\
\hline Point and nonpoint sources & 27 \\
\hline Nonpoint sources only & 7 \\
\hline \multicolumn{2}{|c|}{ Primary Land Use Effects } \\
\hline Forested & 6 \\
\hline Agricultural & 1 \\
\hline Urban & 12 \\
\hline Mixed land use & 15 \\
\hline
\end{tabular}

of dissolved ions than streams affected by urban or agricultural activities. Concentrations of plant nutrients (nitrogen and phosphorus) are usually low (blue dots in figs. 2 and 3), so that conditions favoring excessive algal growth (sometimes called cultural eutrophication) are rare. In clean streams, concentrations of nitrogen are typically less than 0.5 milligram per liter. Concentrations of ammonia nitrogen, which is toxic to fish, are below detection limits. Synthetic organic chemicals and many trace metals are absent.

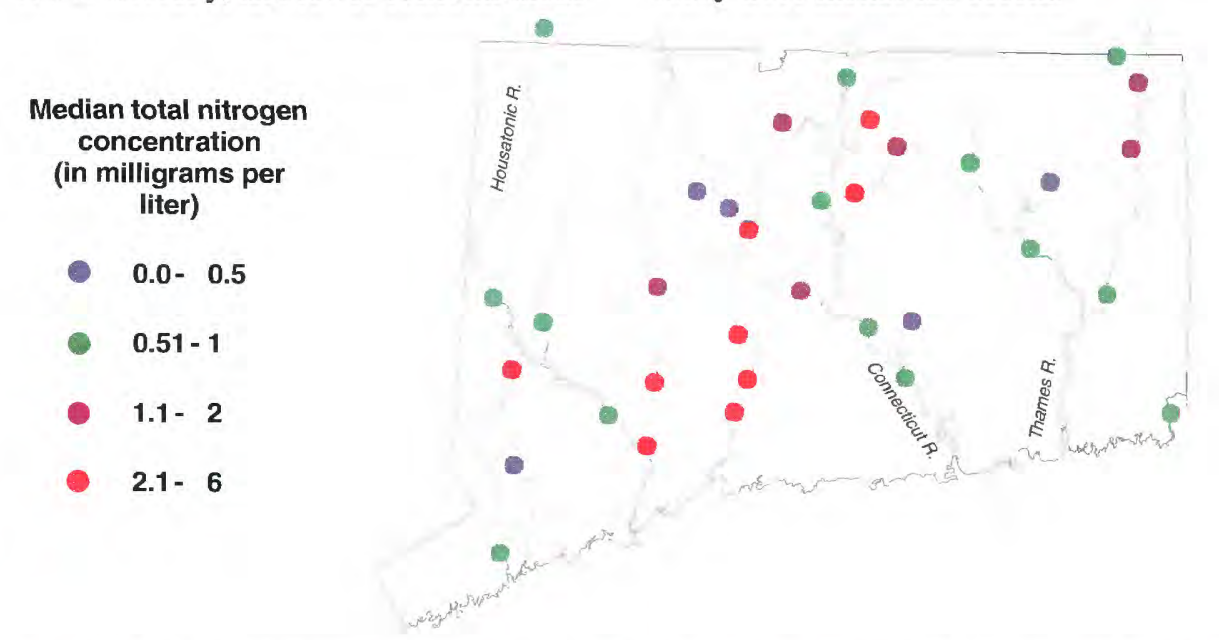

Figure 2. Distribution of median concentrations of total nitrogen in streams in Connecticut, 1988-97. 
Ideally, information on near-natural conditions should come from drainage basins with minimal or no development. Stations monitoring the Salmon, Shepaug, and Saugatuck Rivers. Burlington Brook, and the Farmington River at Unionville. have traditionally been considered "reference sites," which provide information on near-natural conditions. (Four of these five stations are among the stations with the lowest median nitrogen concentrations; see fig. 2). Long-term trends in some constituents, however, show the effects of increased land development in these drainage basins (Trench, 1996). These stations may be more valuable as indicators of water-quality changes in developing rural areas than as true reference sites.

\section{What are the important differences in water quality between clean and deteriorated streams?}

In contrast to near-natural stream quality, streams in highly urbanized drainage basins may be characterized by concentrations of dissolved oxygen that are below ideal levels for aquatic life. Turbidity, bacterial concentrations (purple and red dots in fig. 4), and concentrations of dissolved ions are higher in urban streams than in streams in sparsely developed basins. Concentrations of phosphorus often exceed 0.1 milligram per liter. creating conditions favorable for excessive algal growth and related depletion of dissolved oxygen (purple and red dots in fig. 3). Ammonia, synthetic organic chemicals, and trace metals may be detectable.

Nitrogen concentrations are highest in streams that drain small, highly urbanized basins with large point discharges, and in a small basin with intensive agricultural land use (red dots in fig. 2); concentrations are lowest in sparsely developed forested basins (blue dots in fig. 2). Nitrogen concentrations in the Connecticut River (four green dots in fig. 2) are intermediate, indicating the combined effects of discharges from large municipal point sources and dilution by clean streamflow from forested tributary basins.

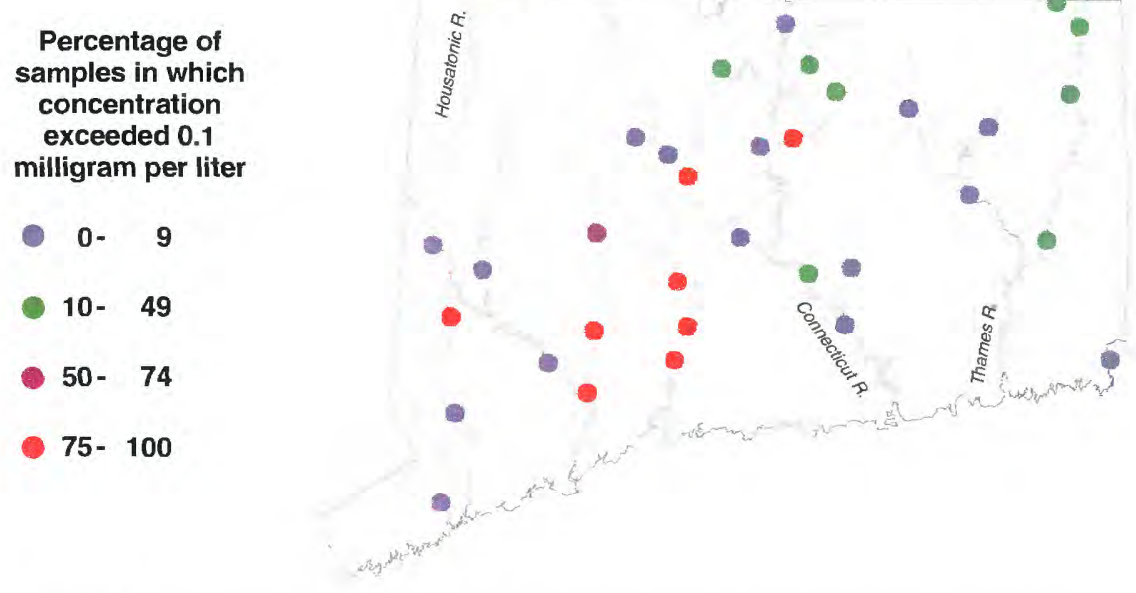

Figure 3. Percentage of samples in which concentration of total phosphorus exceeded 0.1 milligram per liter at monitoring stations in Connecticut, 1988-97. [Concentrations greater than 0.1 milligram per liter are likely to cause eutrophication in flowing streams; lower concentrations may cause eutrophication in still water.]

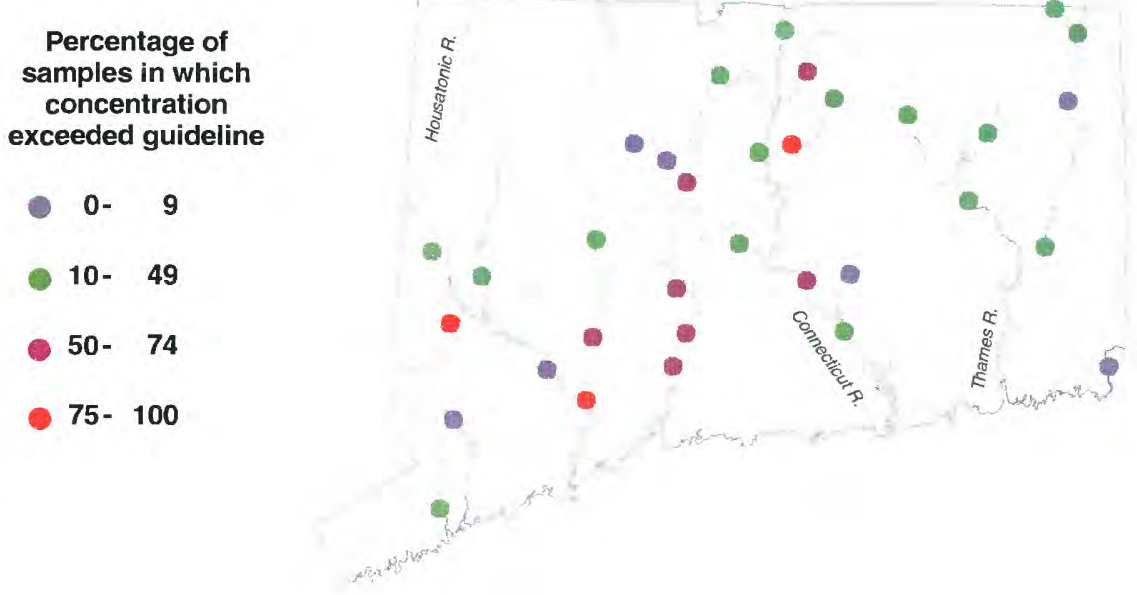

Figure 4. Percentage of samples in which concentration of fecal coliform bacteria exceeded 400 colonies per 100 milliliters (a guideline for evaluating the general sanitary quality of water) at monitoring stations in Connecticut, 1988-97.

\section{Classification and Standards}

The Connecticut Water-Quality Standards document (Connecticut Department of Environmental Protection, 1996) establishes water-quality classification for all State water, as required by State and Federal law. It also establishes criteria for approximately $100 \mathrm{common}$ water-quality constituents and toxic pollutants. Data from the monitoring program are used extensively to determine baseline conditions for criteria development and to monitor compliance with established standards.

Information from the monitoring program helps water managers and scientists assess the health of watersheds. Measures of specific waterquality characteristics are used to define criteria to classify streams and to determine whether or not streams meet their classification standards. By understanding the differences in water quality between clean and deteriorated streams, water managers can recognize the importance of subtle changes in water quality, identify aquatic habitats that require improvement, assess the severity of water-quality problems in highly developed basins, and measure progress toward improved water quality and attainment of water-quality classification goals. 


\section{Does water quality change at different times of year?}

Seasonal variations in water quality are common in Connecticut streams.

Streams that meet established water-quality standards at one time of the year may not meet these standards during all seasons and conditions. At each station, a sufficient sampling frequency is necessary to define seasonal water-quality variations.

Many water-quality conditions are affected by stream discharge, which varies seasonally depending on variations in precipitation, snowmelt, and uptake of water by plants. For example, in an urban stream such as the Hockanum River, concentrations of nitrate (a form of nitrogen) are typically highest at low streamflows and lowest at high streamflows (fig. 5). Nitrate in urban streams comes primarily from treated wastewater, which constitutes a substantial percentage of the Hockanum's streamflow during the low flows of late summer and early fall. During high streamflows, by contrast, the effects of wastewater are diluted by storm runoff containing lower concentrations of nitrate.

The values of many water-quality characteristics are related to seasonal streamflow conditions. Stream discharge data are needed for many interpretive purposes, including trend analysis, load estimation (the amount of a substance transported in a given period of time), and water-quality modeling. Only half of the 30 nontidal monitoring stations have continuous streamflow data from a gaging station at the same site (fig. 1).

\section{How often do water-quality problems occur on Connecticut streams?}

Some streams experience water-quality problems intermittently or seasonally. Other streams have chronic water-quality problems. A sampling frequency that cov- ers the range of water-quality conditions in a typical year provides an indication of the frequency of occurrence of water-quality problems. For example, concentrations of fecal coliform bacteria exceed the State guideline for the general sanitary quality of water at some times of the year (fig. 4). When bacterial concentrations exceed this guideline, there may be public health risks, and State and local officials take action to determine the safety of the water for contact recreation such as swimming. In some streams, typically those that receive wastewater discharges and urban runoff, the guideline is exceeded in half or more of the samples (purple and red dots in fig. 4). In forested drainage basins with few or no point discharges, the guideline is seldom exceeded (blue dots in fig. 4).

\section{How does water quality change as the water flows downstream?}

Streams are dynamic environments. Water quality is affected by physical, chemical, and biological processes within the stream, and by changes in land use in the stream's drainage basin, as the water flows downstream.

In drainage basins where tributaries as well as the main streams are monitored, water-quality information can be used to evaluate any downstream changes in water quality and the contribution of different subbasins to the main stream. In the Farmington River Basin, for example, concentrations of total nitrogen are low in forested headwater basins, such as Burlington Brook (fig. 6). Concentrations are higher in another tributary, the Still River, which receives some municipal wastewater. On the main stem of the Farmington River at Unionville, the effects of small upstream wastewater discharges and agricultural areas are substantially diluted by clean water from a largely forested $(87$ percent) drainage basin. Farther downstream. the Pequabuck River, a highly

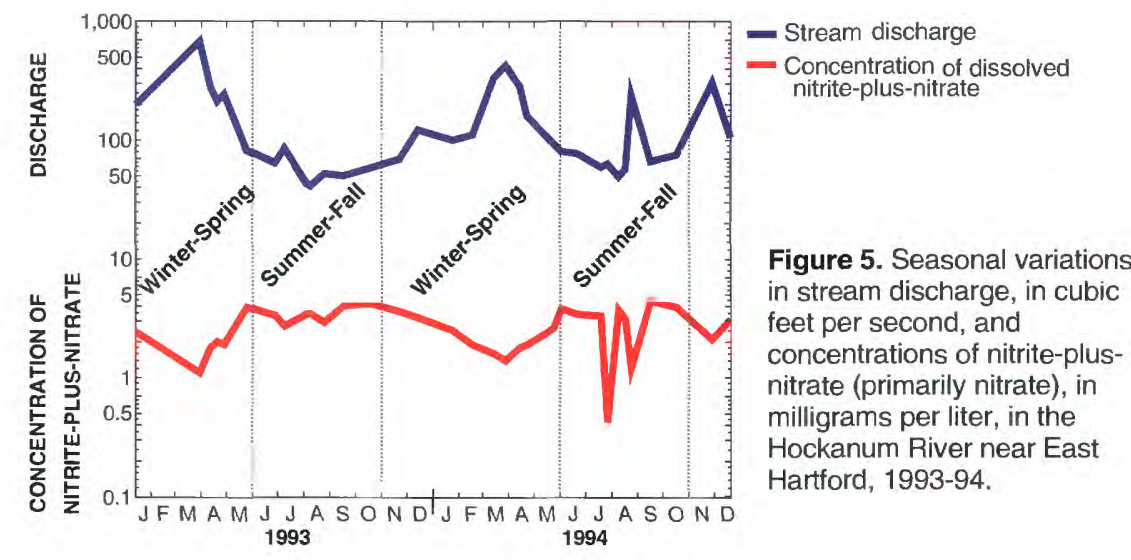

urbanized tributary with large point discharges, has high concentrations of nitrogen. Water quality on the main stem of the Farmington River at Avon and

Tariffville is affected by the upstream inflow of the Pequabuck River, as well as by local wastewater discharges and agricultural activities. Consequently these stations have higher median concentrations than the station at Unionville, and also greater variability in concentration (fig. 6).

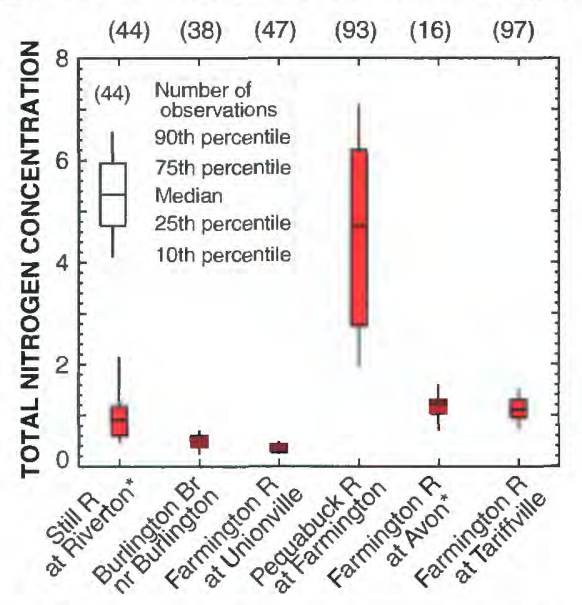

Figure 6. Variations in total nitrogen concentration (in milligrams per liter) in the Farmington River Basin, 1988-97. [ ${ }^{\star}$, discontinued station]

\section{How do hydrologic modifications such as dams affect stream quality?}

Hydrologic modifications have a substantial effect on stream-water quality in some drainage basins. For example, artificial impoundments along a river slow the stream velocity; sediment and other suspended materials settle, and concentrations of some constituents may be lower downstream from the impoundment. Still water in an impoundment is typically more susceptible to excessive algal growth than water in a flowing stream. If a dam is removed, stream velocity increases, and streambed sediment, possibly including contaminants, is likely to be resuspended.

Ground-water or surface-water diversions, in which water is withdrawn from one drainage basin and transferred for use in another basin, can cause long-term decreases or increases in streamflow in small basins. If flow is decreased, but chemical constituents and nutrients enter the river at the same rate, their concentrations in the stream will increase.

Information about the likely effects of proposed modifications can be used to minimize adverse effects on water quality. Additional sampling may be needed to document the effects of specific projects in basins where hydrologic modifications are proposed. 
How has stream quality changed in Connecticut over the long term?

A trend in water quality is a change over time in the chemical, physical, or biological characteristics of the water. Changes in human use of land and water resources, as well as changes in streamflow, can cause trends in water quality.

Trends in the quality of many Connecticut streams were detected in a study covering the period 1969-88 (Trench, 1996). These trends indicate that wastewater-treatment improvements have resulted in improved water quality on major rivers in the State, as shown, for example, by decreases in phosphorus concentrations and turbidity. Increases in several constituents, including chloride, were detected at several stations, however, indicating some deterioration in water quality (fig. 7).

Water managers and planners use trend information to evaluate the effectiveness of public expenditures for waterquality improvement, to assess the status of achieving established water-quality goals, to evaluate environmental conditions and changes, and to plan remedial or preventive actions. Periodic assessment of water-quality trends is necessary to determine if constituent concentrations have a persistent trend in the same direction, have changed direction, or remain constant at some level.

As the water-quality network is modified periodically, it is important to determine the sampling frequencies and length of record necessary to support a meaningful analysis of water-quality trends. Time-series analysis is a method that can be used to determine the optimal sampling frequency for detecting a constituent trend of a given size over a chosen period of years. Although the optimal sampling frequency may differ for each constituent at each station, preliminary analysis indi-

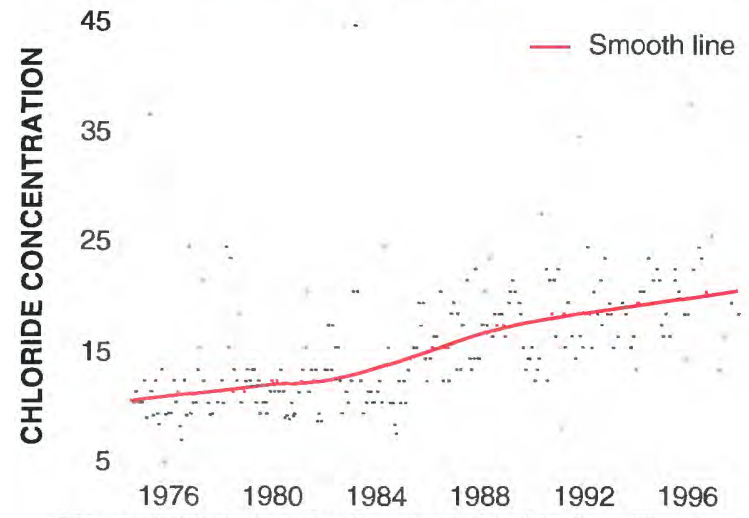

Figure 7. Variations in dissolved chloride (in milligrams per liter) in the Saugatuck River near Redding, 1974-97. cates that a downward trend in nitrogen concentration of about 20 percent over a 5year period could be detected using monthly sampling on the Salmon River (A.V. Vecchia, U.S. Geological Survey, written commun., 1997).

\section{How does the water quality of Connecticut's streams affect Long Island Sound?}

Substances dissolved and suspended in Connecticut's streams are ultimately transported downstream into estuaries and Long Island Sound. Water quality, aquatic habitat, recreational opportunities, and commercial fishing in Long Island Sound are all affected by the quality of freshwater that flows into the Sound. Bacterial concentrations affect recreational safety and shellfish edibility. Metals and other toxic substances may be assimilated by fish and shellfish used for human consumption. Excessive nitrogen fuels excessive algal growth in Long Island Sound. Algal decomposition eventually can lead to hypoxia (low dissolved oxygen), which causes adverse effects on aquatic life, such as reductions in the abundance and diversity of fish and shellfish. The wide range of effects on Long Island Sound indicates that a wide range of water-quality properties and constituents needs to be monitored regularly in Connecticut streams.

It is important to know how much of a substance, such as nitrogen, is transported by a stream (the stream load), as well as its concentration in the stream. For example, the median concentration of total nitrogen in the Connecticut River near the Massachusetts border (fig. 2) is less than 1 milligram per liter of water. Because of its large streamflow, however, the Connecticut River typically transports from 20 to 35 million pounds of nitrogen downstream into tidal areas each year (fig. 8).
All load estimates have a factor of uncertainty, but the degree of uncertainty can be decreased by basing estimates on data that accurately represent the range of streamflow and water-quality conditions, including:

- Continuous streamflow records

- Sufficient years of data to cover a range of streamflow conditions

- Samples that represent conditions in all seasons, particularly winter and early spring when floods transport large constituent loads.

\section{Overall Evaluation - The Current Water-Quality Monitoring Program}

\section{Strengths}

- Long-term water-quality records, long-term continuous streamflow data, good seasonal distribution of data, and data for a wide range of constituents and properties are available for large drainage basins (greater than 100 square miles).

- Data from most large drainage basins are sufficient to support long-term trend analysis and constituent load estimation, providing a good regional picture of constituent trends and transport.

- Trend analyses for large drainage basins can be used to show possible effects of improvements in wastewater treatment or increases in wastewater discharges.

-Water quality is well documented for highly urbanized basins with point-source discharges.

-Water-quality conditions and longterm trends are well documented for a few small (less than 100 square miles), mostly forested drainage basins in the eastern and western uplands.

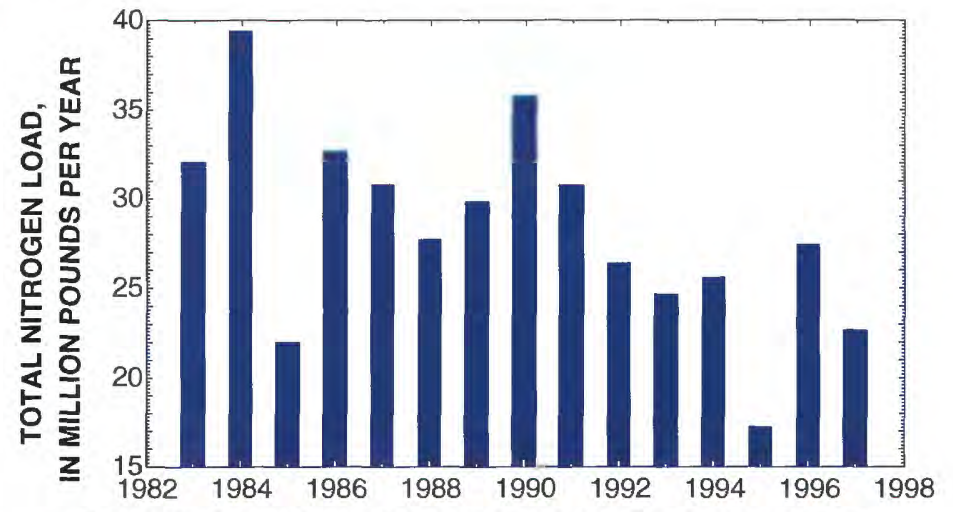

Figure 8. Annual total nitrogen loads for the Connecticut River at Thompsonville, water years 1983-97. 


\section{Deficiencies}

- Constituent trends in five long-term reference basins indicate increasing effects of human activities on water quality.

Although the data can document effects of land development in formerly rural areas, these basins may no longer represent nearnatural conditions in Connecticut.

- Most monitored drainage basins are large (greater than 100 square miles) and their streams receive point discharges. Water-quality interpretation is complicated by the combined effects of forested, agricultural, and urbanized land.

- Most stations with less than 10 years of record monitor small drainage basins (less than or equal to 100 square miles). The degree of uncertainty for trend results and load estimates for these small basins is greater than for long-term stations.

- The monitoring program includes very few small basins with relatively homogeneous land use. This limits analysis of how land use affects water quality.

- Only half the nontidal stations have the continuous streamflow data necessary for constituent load estimation and some forms of trend analysis.

- The current sampling schedule emphasizes summer months, and may not adequately represent winter and early spring conditions when large constituent loads are transported. Sampling during winter and early spring has decreased during the 1990's.

\section{Needs}

- New reference sites may be needed in the least-developed areas of the State because of water-quality changes related to recent land development in long-term reference basins.

- Long-term information is needed in small drainage basins with various intensities of urban and agricultural development, but with no point discharges, to assess accurately the effects of nonpoint sources on water-quality conditions, trends, and constituent loads.

- The seasonal distribution of sampling may need to be adjusted to account accurately for constituent transport in winter and early spring.

- Sampling during floods is necessary to improve or verify constituent load estimates and to support trend analysis in drainage basins without point sources.

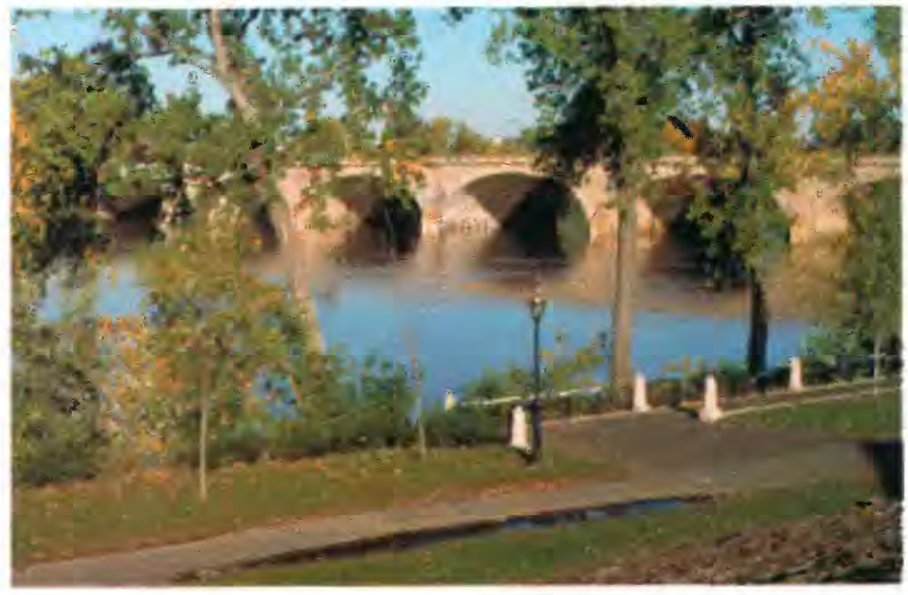

The Connecticut River, looking upstream to the Bulkeley Bridge from East Hartford (photograph by Elaine C. Todd Trench, U.S. Geological Survey).

- Continuous streamflow data are needed to maximize the usefulness of water-quality information at some stations.

- Investigation of estuarine processes is necessary to improve the link of understanding between constituent loads in freshwater streams and water-quality conditions in Long Island Sound.

\section{Summary - Water-Quality Monitoring Now and in the Future}

A well-designed and continuously evolving water-quality network will assist natural-resource managers in developing programs, guidelines, and regulations that will result in real improvement in Connecticut's stream quality. Information from such a network may be used to infer conditions in unmonitored basins, and may be applied to watershed models that predict possible outcomes of management, land use, or population changes. Although the current water-quality program is wellsuited to answer many questions, modifications are necessary to address emerging concerns such as increased development in rural areas, protection of drinking-water sources, recreational water use. and water quality in Long Island Sound.

Monitoring program design and data interpretation are closely linked. The large scope of the monitoring program results in a large information base. This information provides an opportunity to evaluate results of water-quality management efforts and the adequacy of the monitoring program for management and scientific needs.

The USGS and CTDEP continue to assess the objectives of the cooperative monitoring program and interpret data collected through the program. Future efforts can be directed toward maintaining critical monitoring locations, filling identified gaps in monitoring design, and acquiring key information. Careful attention to the necessary information base for watershed science in Connecticut will help to ensure that management and policy decisions can be informed by solid scientific results.

\section{Suggestions for Further Reading}

Connecticut Department of Environmental Protection, 1994, The State of Connecticut 1994 Water Quality Report to Congress, prepared pursuant to Clean Water Act Section 305(b): Hartford, Conn., Bureau of Water Management, $97 \mathrm{p}$.

--_- 1996, Water Quality Standards: Hartford, Conn., Bureau of Water Management, 47 p.

Trench, E.C.T., 1996, Trends in surface-water quality in Connecticut, 1969-88: U.S. Geological Survey Water-Resources Investigations Report 96-4161, $176 \mathrm{p}$.

Zimmerman, M.J., 1997, Trends in nitrogen and phosphorus concentrations in southern New England streams, 1974-92: U.S. Geological Survey Fact Sheet 001-97. 4 p.

-Elaine C. Todd Trench and Steven S. Kiesman; lavout by B.A. Korzendorfer

For further information contact District Chief U.S. Geological Survey 101 Pitkin St. East Hartford, CT 06108 (860) 291-6740 Internet-http://www.usgs.gov http://conn.er.usgs.gov 